Tinjauan Pustaka

\title{
Epistaksis dan Hipertensi : Adakah Hubungannya?
}

\author{
Bestari J Budiman, Al Hafiz
}

\begin{abstract}
Abstrak
Latar Belakang: Epistaksis merupakan suatu kondisi klinis yang sering ditemui dan dapat terjadi pada semua umur dengan banyak variasi penyebabnya. Salah satu faktor risiko yang diduga ikut berperan dalam terjadinya epistaksis adalah hipertensi. Tujuan: Menjelaskan hubungan antara epistaksis dengan hipertensi. Tinjauan Pustaka: Hipertensi diduga tidak menyebabkan epistaksis secara langsung, tapi memperberat episode epistaksis. Mengendalikan tekanan darah sebagai salah satu faktor risiko, akan menurunkan insiden terjadinya epistaksis. Di ruang gawat darurat, pemberian obat anti hipertensi diberikan sebelum atau bersamaan dengan manajemen epistaksis itu sendiri. Kesimpulan: Terdapat hubungan antara epistaksis dengan hipertensi yang berlangsung lama dan adanya hipertrofi ventrikel kiri.
\end{abstract}

Kata kunci : Hipertensi, kegawatdaruratan, penatalaksanaan epistaksis.

\section{Abstract}

Background: Epistaxis is a common clinical problem in all age groups with varied etiological factors. Hypertension has been suggested as a risk factor in epistaxis case. Purpose: To explain relationship between epistaxis and hypertension. Review: It has been suggested that hypertension does not cause epistaxis directly, but hypertension prolongs the episode of epistaxis when it does occur. The controlling for blood pressure as a risk factor will be decreased the incidencies of epistaxis. In emergency rooms, high blood pressure is usually treated before or in parallel with the management of epistaxis. Conclusion: There was an association between epistaxis and long duration of hypertension in adult and left ventricle hypertrophy.

Key words : Hypertension, emergency case, management of epistaxis.

Alamat Korespondensi: Al Hafiz, Bagian THT Bedah Kepala dan Leher RSUP Dr. M. Djamil, Jln. Perintis Kemerdekaan Padang. E-mail: dr_hafizdjosan@yahoo.com

\section{Pendahuluan}

Epistaksis berasal dari bahasa Yunani epistazo yang berarti hidung berdarah. Penanganan epistaksis dengan menekan ala nasi telah diperkenalkan sejak zaman Hipokrates. Cave Michael (1871), James Little (1879) dan Wilhelm Kiesselbach merupakan ahli-ahli yang pertama kali mengidentifikasi cabang-cabang pembuluh darah yang berada di bagian anterior septum nasi sebagai sumber epistaksis. ${ }^{1}$

Dikutip dari Dewar, Mitchell menemukan 4,5\% dari 374 orang yang dirawat dengan hipertensi, memiliki riwayat epistaksis. ${ }^{2}$

Sedangkan Herkner dkk melaporkan dari 213 orang pasien yang datang ke unit gawat darurat dengan epistaksis, ditemukan 33 orang pasien (15,5\%) dengan peningkatan tekanan darah.

\section{Anatomi dan Pendarahan Rongga Hidung}

Pembuluh darah utama di hidung berasal dari arteri karotis interna (AKI) dan karotis eksterna (AKE). ${ }^{4}$

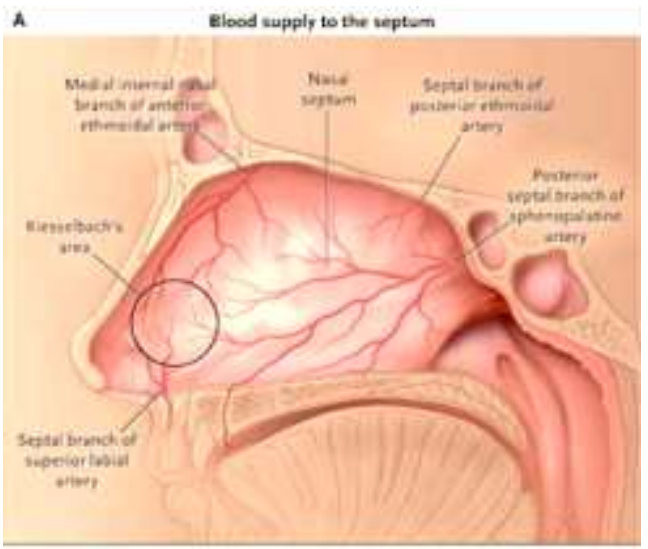

Gambar 1. Pembuluh darah di daerah septum nasi. ${ }^{5}$

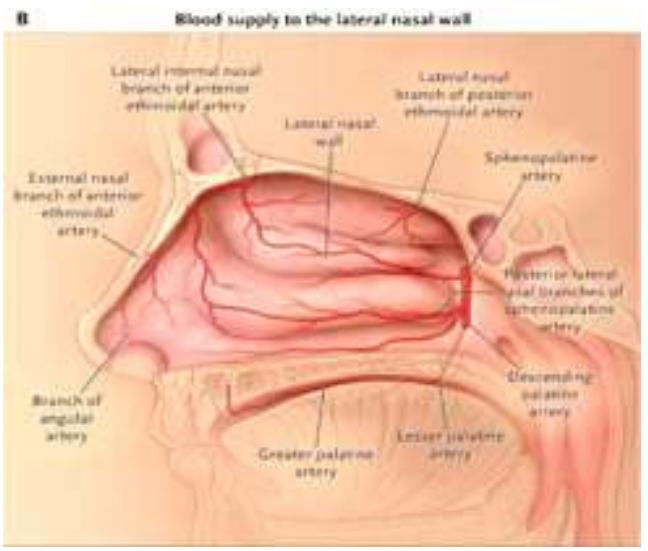

Gambar 2. Pembuluh darah di dinding lateral hidung. ${ }^{5}$ 
Arteri optalmika, yang merupakan cabang dari $\mathrm{AKI}$, bercabang dua menjadi arteri ethmoidalis anterior dan posterior. Cabang anterior lebih besar dibanding cabang posterior dan pada bagian medial akan melintasi atap rongga hidung, untuk mendarahi bagian superior dari septum nasi dan dinding lateral hidung. AKE bercabang menjadi arteri fasialis dan arteri maksilaris interna. Arteri fasialis memperdarahi bagian anterior hidung melalui arteri labialis superior. ${ }^{4}$

Arteri maksilaris interna di fossa pterigopalatina bercabang menjadi arteri sfenopalatina, arteri nasalis posterior dan arteri palatina mayor. Arteri sfenopalatina memasuki rongga hidung pada bagian posterior konka media, memperdarahi daerah septum dan sebagian dinding lateral hidung. ${ }^{4}$

Pada bagian anterior septum, anastomosis dari arteri sfenopalatina, palatina mayor, ethmoidalis anterior dan labialis superior (cabang dari arteri fasialis), membentuk plexus Kiesselbach atau Little's area. ${ }^{4,6,7}$

Pada posterior dinding lateral hidung, bagian akhir dari konka media terdapat plexus Woodruff yang merupakan anastomosis dari arteri sfenopalatina, nasalis posterior dan faringeal asendens. ${ }^{4,6,7}$

Epistaksis anterior sering mengenai daerah plexus Kiesselbach. Epistaksis anterior lebih mudah terlihat sumber perdarahannya sehingga mudah diatasi dibandingkan epistaksis posterior. Batas yang membagi antara epistaksis anterior dan epistaksis posterior adalah ostium sinus maksilaris. ${ }^{4,6,7}$

\section{Hipertensi}

Dalam rekomendasi penatalaksanaan hipertensi yang dikeluarkan oleh the $7^{\text {th }}$ of Joint National Committe on Prevention, Detection, Evaluation, and Treatment of High Blood Pressure (JNC-7) 2003, World Health Organization/ International Society of Hypertension (WHO-ISH) 1999 dinyatakan bahwa definisi hipertensi sama untuk semua golongan umur di atas 18 tahun. Pengobatan juga bukan berdasarkan penggolongan umur, melainkan berdasarkan tingkat tekanan darah dan adanya risiko kardiovaskuler pada pasien. ${ }^{8}$ $7:^{8}$

Berikut klasifikasi hipertensi berdasarkan JNC-

- Normal : Sistolik $<120 \mathrm{mmHg}$, Diastolik dan $<80$ $\mathrm{mmHg}$.

- Prehipertensi : Sistolik 120-139 mmHg, Diastolik atau $80-90 \mathrm{mmHg}$.

- Hipertensi stadium 1 : Sistolik 140-159 mmHg, Diastolik atau 90-99 $\mathrm{mmHg}$.

- Hipertensi stadium 2 : Sistolik $\geq 160 \mathrm{mmHg}$, Diastolik atau $\geq 100 \mathrm{mmHg}$.

- Isolated Systolic Hypertension : Sistolik $\geq 140$ $\mathrm{mmHg}$, Diastolik dan $<90 \mathrm{mmHg}$.

Berdasarkan pedoman dari European Society of Hypertension (ESH) \& European Society of Cardiology (ESC)-2003 membagi hipertensi dalam 3 tingkatan sedangkan JNC-7 membagi dalam 2 stadium. Menurut ESH \& ESC-2003 dan JNC-7 pengobatan farmakologik dimulai pada hipertensi tingkat 1 atau TD 140-159/90-99 mmHg, sedangkan menurut British Society of Hypertension (BSH-IV 2004) memulai pada tekanan darah $\geq 160 / 100 \mathrm{mmHg}$. Pengobatan farmakologik dapat diberikan pada tekanan darah 140159/90-99 mmHg bila terdapat kerusakan organ target, penyakit kardiovaskuler, diabetes melitus, atau risiko kardiovaskuler dalam 10 tahun mencapai $\geq 20 \%$.
Menurut JNC-7 diuretik tiazid (DT) merupakan pilihan awal pengobatan hipertensi stadium 1 tanpa indikasi memaksa (compelling indications). Penggunaan obat antihipertensi golongan angiotensin converting enzyme inhibor inhibitors (ACE-i), angiotensin receptor II blockers (ARB), beta blokers (BB), atau calcium channel blocker (CCB) dapat dipertimbangkan sebagai obat tunggal atau kombinasi. Hipertensi stadium 2 membutuhkan kombinasi DT dengan obat antihipertensi yang lain. ${ }^{8,9}$

Gagal jantung, pasca infark miokard, risiko tinggi penyakit jantung koroner, diabetes melitus, penyakit ginjal kronik, dan kemungkinan stroke berulang merupakan indikasi untuk memilih obat antihipertensi tertentu. ${ }^{8,9}$

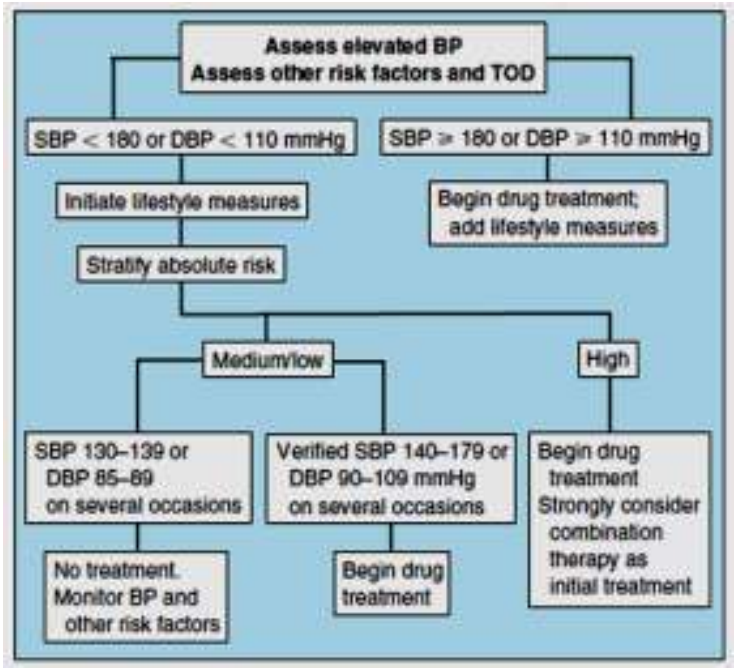

Gambar 4. Penatalaksanaan awal pasien hipertensi. ${ }^{9}$

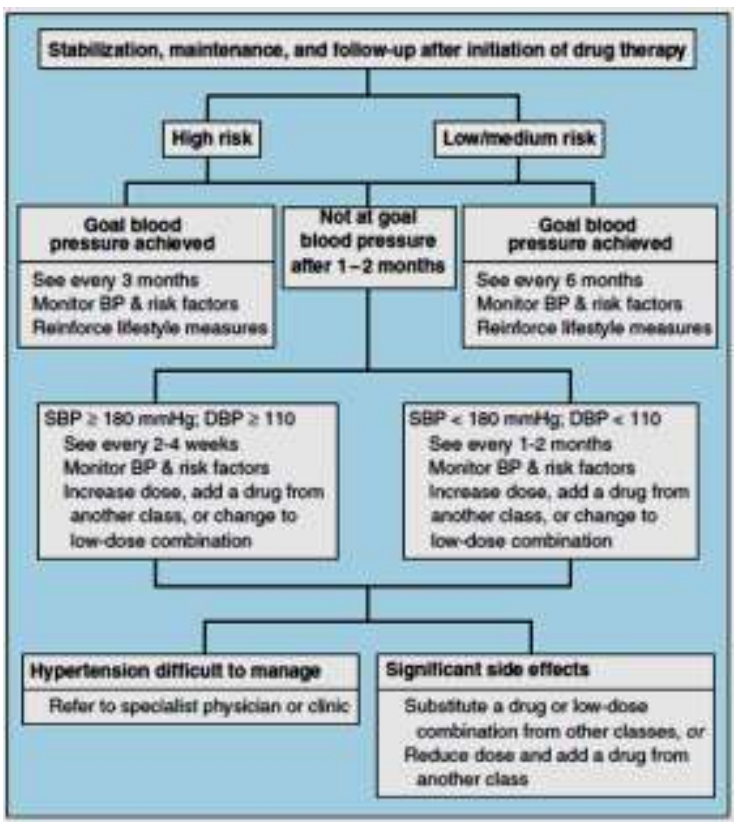

Gambar 5. Penatalaksanaan pasien hipertensi setelah pemberian obat antihipertensi. $^{9}$

\section{Pengaruh Hipertensi Pada Sistem Vaskularisasi}

Lebih dari setengah abad yang lalu, penelitian hipertensi telah membentuk paradigma yang fokus pada regulasi sistem neuroendokrin vasoaktif sistemik yang mengatur tonus vaskuler dan hemostasis cairan 
dan elektrolit pada ginjal. Hal ini menunjukkan bahwa hipertensi disebabkan oleh gangguan hemostasis pengaturan level hormon di sirkulasi dan aktivitas sistem saraf simpatis. Dalam hal ini secara konseptual, pembuluh darah sebagai sistem penerima pasif aksi sistemik faktor neuroendokrin. ${ }^{9,10}$

Sebuah konsep yang telah berkembang dalam patofisiologi hipertensi adalah kontribusi perubahan struktur vaskuler (remodelling vaskuler). Sekarang telah diketahui tonus dapat berubah melalui proses akut dan pembuluh darah dapat merubah strukturnya melalui proses kronik sebagai respon terhadap kondisi tertentu. 9,10

Remodelling vaskuler adalah suatu proses adaptif sebagai respon terhadap perubahan kronik pada kondisi hemodinamik atau faktor hormonal. Substansi vasoaktif dapat meregulasi homeostasis vaskuler melalui efek jangka pendek pada tonus vaskuler dan efek jangka panjang pada struktur vaskuler. Ketidakseimbangan kedua hal inilah yang menimbulkan vasokonstriksi dan hipertrofi vaskuler sehingga timbul hipertensi. ${ }^{9,10}$

Perubahan dalam migrasi sel dan proliferasi, perubahan matriks adalah kunci terjadinya remodelling vaskuler. Pada hipertensi, perubahan struktur pembuluh darah adalah yang mungkin bertanggung jawab atas peningkatan tekanan dan aliran darah, ketidakseimbangan substansi vasoaktif dan disfungsi endotel. ${ }^{9,10}$

Pada tahap awal hipertensi primer curah jantung meningkat dan tekanan perifer normal, hal ini disebabkan oleh peningkatan aktifitas saraf simpatik. Tahap selanjutnya curah jantung dan tekanan perifer meningkat karena efek antiregulasi (mekanisme tubuh untuk mempertahankan keadaan hemodinamik yang normal). ${ }^{11}$

Pada hipertensi terjadi perubahan struktur pembuluh darah, sebagai tanggapan terhadap peningkatan tekanan arterial. Dengan perubahan struktur pembuluh darah demikian maka perbandingan lebar lumen meningkat baik karena peningkatan massa otot atau karena pengaturan unsur-unsur seluler dan bukan seluler. Kerusakan vaskuler akibat hipertensi terlihat pada seluruh pembuluh darah perifer. ${ }^{11}$

Contoh-contoh klinis bentuk remodelling vaskuler meliputi: ${ }^{11}$

1) Pelebaran pembuluh darah yang berkaitan dengan kecepatan aliran darah yang tinggi. Dapat terbentuk fistula arteriovena.

2) Hilangnya sel atau proteolisis matriks pembuluh darah akibat pembentukan aneurisma.

3) Pengurangan massa dan ukuran pembuluh darah terjadi karena pengurangan aliran darah jangka panjang.

4) Mikrosirkulasi yang jarang atau hilangnya area kapiler yang menyebabkan meningkatnya kejadian hipertensi dan iskemia jaringan.

5) Arsitektur dinding pembuluh darah juga berubah yang meliputi trombosis, migrasi dan proliferasi selsel vaskuler, produksi matriks dan infiltrasi sel-sel inflamasi.

\section{Faktor-Faktor Etiologi Epistaksis}

Pada banyak kasus, tidak mudah untuk mencari penyebab terjadinya epistaksis. Etiologi epistaksis dapat dari banyak faktor. Secara garis besar dapat dikelompokkan menjadi dua, yaitu faktor lokal dan faktor sistemik. ${ }^{4,6,7,12}$ a. Faktor Lokal

Beberapa faktor lokal yang dapat menyebabkan terjadinya epistaksis antara lain:

- Trauma nasal.

- $\quad$ Obat semprot hidung (nasal spray). Penggunaan obat semprot hidung secara terus menerus, terutama golongan kortikosteroid, dapat menyebabkan epistaksis intermitten. Terdapat kerusakan epitel pada septum nasi. Epitel ini akan mudah berdarah jika krusta terlepas. Pemakaian fluticasone semprot hidung selama 4-6 bulan, belum menimbulkan efek samping pada mukosa. $^{12}$

- Kelainan anatomi: adanya spina, krista dan deviasi septum.

- $\quad$ Tumor intranasal atau sinonasal. Sering ditandai dengan adanya riwayat epistaksis yang berulang.

- Iritasi zat kimia, obat-obatan atau narkotika. Seperti dekongestan topikal dan kokain. ${ }^{12}$

- Iritasi karena pemakaian oksigen: Continuous Positive Airway Pressure (CPAP).

- Kelainan vaskuler. Seperti kelainan yang dikenal dengan Wagener's granulomatosis (kelainan yang didapat). ${ }^{12}$

b. Faktor Sistemik

Hipertensi tidak berhubungan secara langsung dengan epistaksis. Arteriosklerosis pada pasien hipertensi membuat terjadinya penurunan kemampuan hemostasis dan kekakuan pembuluh darah. ${ }^{1}$

Penyebab epistaksis yang bersifat sistemik antara lain:

- Sindrom Rendu Osler Weber (hereditary hemorrhagic telangectasia) merupakan kelainan bawaan yang diturunkan secara autosom dominan. Trauma ringan pada mukosa hidung akan menyebabkan perdarahan yang hebat. Hal ini disebabkan oleh melemahnya gerakan kontraktilitas pembuluh darah serta terdapatnya fistula arteriovenous.

- Efek sistemik obat-obatan golongan antikoagulansia (heparin, warfarin) dan antiplatelets (aspirin, clopidogrel). ${ }^{12}$

- Kegagalan fungsi organ seperti uremia dan sirosis hepatis. $^{12}$

- $\quad$ Atheroslerosis, hipertensi dan alkohol. ${ }^{12}$

- Kelainan hormonal. Seperti kelebihan hormon adrenokortikosteroid atau hormon mineralokortikoid, pheochromocytoma, hyperthyroidism atau hypothyroidism, kelebihan hormon pertumbuhan dan hyperparathyroidism. ${ }^{11}$

\section{Hubungan Epistaksis Dengan Hipertensi}

Menurut Herkner dkk, ada dua hipotesis yang menerangkan kenapa epistaksis dapat terjadi pada pasien-pasien dengan hipertensi. ${ }^{3}$

1. Pasien dengan hipertensi yang lama memiliki kerusakan pembuluh darah yang kronis. Hal ini berisiko terjadi epistaksis terutama pada kenaikan tekanan darah yang abnormal.

2. Pasien epistaksis dengan hipertensi cenderung mengalami perdarahan berulang pada bagian hidung yang kaya dengan persarafan autonom yaitu bagian pertengahan posterior dan bagian diantara konka media dan konka inferior.

Hubungan antara hipertensi dengan kejadian epistaksis masih merupakan suatu yang kontroversial. Adanya kecendrungan peningkatan kejadian epistaksis pada pasien dengan hipertensi yang lama dan hipertrofi 
ventrikel kiri. Tetapi sebagian penulis menemukan sebaliknya. Lubianca dkk (1999), menyatakan tidak ditemukan hubungan yang bermakna antara peningkatan tekanan darah dengan kejadian epistaksis. $^{13}$

Padgham dkk, dikutip dari Temmel, menemukan adanya hubungan antara hipertensi dengan epitaksis terutama epitaksis yang berasal dari meatus medius, tapi tidak ditemukan hubungan dengan beratnya epistaksis. Sedangkan Beran dkk melaporkan common cold, stres, dan kelelahan dilaporkan sering mendahului terjadinya epistaksis. ${ }^{14}$

Ibrashi dkk mengatakan bahwa lesi lokal di hidung yang menyebabkan stagnan aliran pembuluh darah seperti infeksi, atau penyebab lainnya yang menghancurkan dinding pembuluh darah atau mukoperiostealnya yang dapat menjadi pemicu terjadinya epistaksis, maka hipertensi dan aterosklerosis baru akan memainkan peranannya dalam memperberat epistaksis. ${ }^{15}$ Dari Lubianca mengatakan ada tiga faktor lain yang dapat membuat samar diagnosis epistaksis yang disebabkan oleh hipertensi yaitu: 1) kelainan anatomi hidung, 2) bukti adanya kerusakan organ target lain dan 3) kelainan hemostasis. ${ }^{13}$

Hedges (1969), seperti dikutip dari Ibrashi, membandingkan pengaruh hipertensi pada aliran darah di retina dengan aliran darah di hidung. Hasilnya didapatkan pada aliran darah dalam retina didukung oleh tekanan dari intraokuler. Sebaliknya, aliran darah di hidung, tidak ada tekanan pendukung dari mukoperikondrium dan mukoperiostium. Inilah yang mungkin menjelaskan pada pasien hipertensi dengan gejala epistaksis, tapi tidak ada gejala perdarahan retina dan eksudat pada kelompok yang diperiksa. Perdarahan di retina berhubungan dengan penyebab sistemik seperti diabetes melitus, atau penyebab lokal seperti tekanan intraokuler yang rendah. ${ }^{15}$

Herkner mendapatkan dari 213 orang pasien yang datang ke unit gawat darurat dengan epistaksis, mempunyai tekanan darah sistolik 161 (157-165) $\mathrm{mmHg}$ dan tekanan darah diastolik $84(82-86)$ $\mathrm{mmHg}$ serta pada hipertensi stadium $3(\geq 180 / \geq 110$ $\mathrm{mmHg})^{3}$

Padgham melaporkan pada hipertensi ringan dan sedang, terbukti mempunyai hubungan dengan kejadian epistaksis di meatus medius, tapi tidak di bagian hidung yang lain. Tidak terbukti ada hubungan kejadian epistaksis dengan konsumsi aspirin, obat antiinflamasi non steroid, tingkat keparahan dan bagian hidung yang mengalami perdarahan. ${ }^{16}$

Knopfholz dkk mengatakan hipertensi tidak berhubungan dengan beratnya epistaksis yang terjadi. Tetapi hipertensi terbukti dapat membuat kerusakan yang berat pada pembuluh darah di hidung (terjadi proses degenerasi perubahan jaringan fibrous di tunika media) yang dalam jangka waktu yang lama merupakan faktor risiko terjadinya epistaksis. ${ }^{17}$

Epistaksis bukanlah termasuk gejala kasus hipertensi emergensi. Kesimpulan ini didapatkan oleh Lima Jr dkk dalam penelitian tentang hubungan epistaksis dengan kasus hipertensi emergensi. ${ }^{18}$

Fakta baru yang ditemukan oleh Herkner dkk (2002) bahwa angka kejadian epistaksis pasca operasi mengalami peningkatan pada pasien dengan riwayat hipertensi yang lama. Tidak ditemukan hubungan dengan beratnya derajat hipertensi. ${ }^{19}$

\section{Penatalaksanaan Epistaksis Dengan Hipertensi}

Charles dan Corrigan ${ }^{20}$ melakukan penelitian terhadap pasien epistaksis dengan hipertensi. Didapatkan dua puluh enam orang pasien yang dirawat karena hipertensi semuanya mempunyai gejala epistaksis.

Dari Shaheen ${ }^{21}$, melakukan penelitian terhadap arteri ukuran sedang dan kecil pada pasien usia pertengahan dan tua, ia mendapatkan telah terjadi perubahan lapisan otot pada tunika media menjadi lapisan kolagen. Perubahan bervariasi mulai hanya berupa intertitial fibrosis sampai pergantian yang komplit lapisan otot dengan jaringan kolagen. ${ }^{21}$

Angka kejadian epistaksis tertinggi terjadi pada tekanan darah diastolik $100 \mathrm{mmHg}$ yaitu 10 orang dari 72 orang pasien $(13,9 \%) .{ }^{21}$ Sedangkan Herkner $\mathrm{dkk}^{22}$, mendapatkan ada 33 pasien dari 213 kunjungan ke unit gawat darurat yang mengalami epistaksis disertai dengan peningkatan tekanan darahnya. ${ }^{22}$

Massick ${ }^{23}$, membuktikan bahwa tidak terdapat hubungan yang jelas antara epistaksis dengan hipertensi (unproven relationship).

Menurut Massick, penatalaksanaan epistaksis dengan hipertensi secara umum sama dengan kasus epistaksis lainnya. Penilaian pertama yang harus dilakukan adalah menilai stabilitas hemodinamik pasien. Kehilangan darah yang banyak serta diperhatikan tanda-tanda terjadinya syok hipovelemik. ${ }^{23}$

Salah satu manifestasi klinis yang tersering adalah epistaksis yang berulang hingga memerlukan transfusi darah. Bila perlu dengan pemasangan suatu tampon hidung anterior atau posterior dan transfusi plasma kriopresipitat, faktor VIII atau faktor pembekuan lain. ${ }^{7,23}$

Menurut Schwartzbauer dkk (2003), ligasi terhadap arteri sfenopalatina dan nasalis posterior dengan menggunakan metode endoskopi berhasil menghentikan epistaksis yang berulang. ${ }^{24}$

Herkner dkk mengatakan hal yang tidak kalah pentingnya dalam penanganan epistaksis dengan hipertensi ini adalah penanganan lanjutan untuk hipertensinya setelah mereka mendapatkan pengobatan di unit gawat darurat. Herkner mendapatkan lebih sepertiga pasien epistaksis dengan hipertensi yang berobat di unit gawat darurat tidak mendapatkan pengobatan yang adekuat untuk hipertensinya selama di rumah. ${ }^{3}$

Dikutip dari hasil penelitian yang dilakukan oleh Secchi (2009), epistaksis dengan hipertensi ditemukan pada 22 kasus (36\%) dari total kasus epistaksis. Penelitian lain mendapatkan prevalensi 24 64\%. Dari 22 kasus ini penanganan yang diberikan berupa pemasangan tampon anteroposterior dan kontrol tekanan darah sebanyak 18 kasus. Sedangkan 4 kasus lagi dilakukan ligasi arteri sfenoid. ${ }^{25}$

Sebagai ringkasan, dapat dikemukakan prinsip penatalaksanaan epistaksis dengan hipertensi secara umum sama dengan kasus epistaksis lainnya. Penanganan epistaksis dimulai dengan melakukan anamnesis yang ringkas dan tepat, serta pemeriksaan fisik, bersamaan dengan persiapan untuk menghentikan epistaksis. Hubungan hipertensi dengan terjadinya epistaksis masih belum jelas. Perubahan endotel pembuluh darah arteri pada kasus hipertensi menjadi dasar adanya hubungan antara epistaksis dengan hipertensi. Terdapat bukti sementara bahwa 
ada hubungan antara hipertrofi ventrikel kiri dan epistaksis dengan hipertensi yang berlangsung lama.

\section{Daftar Pustaka}

1. Nwaorgu OGB. Epistaxis: An Overview. Annals of Ibadan Postgraduate Medicine 2004; 1(2): 32-7.

2. Dewar HA. Epistaxis in Hypertension. British Medical Journal 1959; 5115: 169-70.

3. Herkner $\mathrm{H}$, Laggner $\mathrm{AN}$, Muller M, Formanek $\mathrm{M}$, Bur A et al. Hypertension in Patients Presenting With Epistaxis. Annals of Emergency Medicine 2000; 35(2): 126-30.

4. Kanowitz SJ, Citardi MJ, Batra PS. Contemporary Management Strategies for Epistaxis. In: Stucker FJ, de Souza C, Kenyon GS et al editors. Rhinology and Facial Plastic Surgery. Berlin: Springer; 2009. p. 139-49.

5. Schlosser RJ. Epistaxis. N Engl J Med 2009; 7849.

6. Dhingra PL. Epistaxis. In: Disease of Ear, Nose and Throat, $4^{\text {th }}$ Edition. Noida: Elsivier; 2009. p. 166-70.

7. Wormald PJ. Epistaxis. In: Bailey BJ, Johnson JT et al editors. Otolaryngology Head and Neck Surgery, $4^{\text {th }}$ Ed Vol 1. Philadelphia: Lippincott Williams \& Wilkins; 2006. p. 506-14.

8. Prodjosudjadi W. The Update Evidences on Hypertension Management. In: Suhardjono, Mayza A, Soenarta AA dkk editors. The $3^{\text {rd }}$ Scientific Meeting on Hypertension. Indonesian Society of Hypertension. Jakarta; 2009: p. 2-6.

9. Kasper DL, Braunwald E, Fauci AS et al. Hypertension. Harrison's Manual of Medicine, $16^{\text {th }}$ edition. New York : McGraw-Hill, 2005. 616-21.

10. Sargowo D. Hypertension and Vascular Molecular Biology Research Review on Biomolecular Mechanism. In: Suhardjono, Mayza A, Soenarta AA dkk editors. The 3rd Scientific Meeting on Hypertension. Indonesian Society of Hypertension. Jakarta: InaSH; 2009. p. 1-23.

11. Idham I, Sanjaya W. Angiotensin-II dan Remodelling Vaskuler. Cermin Dunia Kedokteran 2005; 147: 16-20.

12. Pope LER, Hobbs CGL. Epistaxis: An Update on Current Management. Postgrad Med J 2005; 81: 309-14.

13. Lubianca JF, Fuchs FD, Facco $\mathrm{Sr}$ et al. Is Epistaxis Evidence of End Organ Damage in
Patients With Hypertension? Laryngoscope 1999; 109: 1111-5.

14. Temmel AFP, Quint C, Toth J. Debate about Blood Pressure and Epistaxis Will Continou. British Medical Journal 2001; 322(7295): 1181.

15. Ibrashi F, Sabri N, Eldawi M, Belal A. Effect of Atherosclerosis and Hypertension on Arterial Epistaxis. J Laryngol Otol 1978; 877-81.

16. Padgham N. Epistaxis: Anatomical and Clinical Correlates. J Laryngol Otol 1990; 104: 308-11.

17. Knopfholz J, Lima JE, Neto DP, Faria NJR. Association between Epistaxis and Hypertension: A one year Follow-up After an Index Episode of Nasal Bleeding in Hypertension Patients. International Journal of Cardiology 2009; 134: 107-9.

18. Lima Jr, Knopfholz J. Relationship Between Epistaxis and Arterial Pressoric Blood Levels: is the Epistaxis a Hypertensive Emergency? Am J Hypertensions 2000; 13(4):220.

19. Herkner H, Havel C, Mullner M, Gamper G, Bur A et al. Active Epistaxis at ED Presentation is Associated with Arterial Hypertension. American Journal of Emergency Medicine 2009; 20(2): 92-5.

20. Charles R, Corrigan E. Epistaxis and Hypertension. Posgrad Med J 1977; 53: 260-1.

21. Shaheen $\mathrm{OH}$. Epistaxis. In: Ballantyne J, Groves J et al editors. Scott's Brown's Diseases of the Ear, Nose \& Throat, 4th ed vol 3. London : 1984. 14762.

22. Herkner $\mathrm{H}$, Laggner $\mathrm{AN}$, Muller $\mathrm{M}$ et al. Hypertension in Patients Presenting with Epistaxis. Annals of Emergency Medicine 2000; 35(2): 126-30.

23. Massick D, Tobin EJ. Epistaxis. In: Cummings CW, Flint DW, Harker LA et al editors. Cumming's Otolaryngology Head \& Neck Surgery, $4^{\text {th }}$ Ed Vol 2. Philadelphia : Elsevier Mosby, 2005. 942-61.

24. Schwartzbauer HR, Shete M, Tami TA. Endoscopic Anatomy of the Sphenopalatine and Posterior Nasal Arteries: Implications for the Endoscopic Management of Epistaxis. American Journal of Rhinology 2003; 17(1): 63-6.

25. Secchi MMD, Indolfo MLP, Rabesquine MM, de Castro FB. Epistaxis: Prevailing Factors and Treatment. Intl Arch Otorhinolaryngol Sao Paolo Brazil 2009; 13(4): 381-5. 